University of Nebraska - Lincoln

DigitalCommons@University of Nebraska - Lincoln

Library Philosophy and Practice (e-journal)

Libraries at University of Nebraska-Lincoln

Summer 7-13-2019

APPLICATION OF WEB 2.0 IN PRIVATE
UNIVERSITY LIBRARIES OF NORTHERN
NIGERIA USING THE THEORY OF MANNES
LIBRARY 2.0.

ABDULLAHI BALA SHEHU

University of Delhi (DLIS), abeeshe@yahoo.com

SINGH K.P. PhD

University of Delhi (DLIS), kpsingh330@gmail.com

Follow this and additional works at: https://digitalcommons.unl.edu/libphilprac

Part of the Library and Information Science Commons

SHEHU, ABDULLAHI BALA and K.P., SINGH PhD, "APPLICATION OF WEB 2.0 IN PRIVATE UNIVERSITY LIBRARIES OF NORTHERN NIGERIA USING THE THEORY OF MANNES LIBRARY 2.0." (2019). Library Philosophy and Practice (e-journal). 2801.

https://digitalcommons.unl.edu/libphilprac/2801 


\title{
APPLICATION OFWEB 2.0 IN PRIVATE UNIVERSITY LIBRARIES OF NORTHERN NIGERIA USING THE THEORY OF MANNES LIBRARY 2.0.
}

BY

\author{
${ }^{1}$ ABDULLAHI BALA SHEHU \\ abeeshe@yahoo.com \\ $\&$ \\ ${ }^{2}$ SINGH.K.P. \\ Kpsingh330@gmail.com
}

\begin{abstract}
This paper investigated application of web 2.0 to private university libraries of northern part of Nigeria based on Mannes theory which emphasizes on changing scenario of librarianship with the presence of the web, (10) private university libraries website which are of quality and ICT compliant by Nigerian standard were surveyed to identify the presence of web 2.0 tool application and purpose for application. Only (4) 40\% had applied web 2.0 tool, the most applied web tool was WebOPAC followed by social networking sites, and (1) private university library had applied RSS, no other web tool have been applied. Even with the web 2.0 boom and advantages web 2.0 provides to library professional for interaction, the application is still very much low in Nigerian libraries. The study recommends Training of library professionals, provision of ICT infrastructure, restructuring of library school curriculum.
\end{abstract}

Key words: Application, Web 2.0, Private university libraries, Websites,

\section{Introduction}

Internet offers a wide range of free professional tools that can be adopted by libraries to be used for a variety of purposes, especially improved service delivery, in recent years, a number of digital and networking tools have emerged on the internet, These digital applications, enabling interaction, collaboration and sharing among users, are generally referred to as Web 2.0 (Ebrahimzadeh, et al., 2008). The new wave of applications of Web 2.0-related technologies in libraries has gained increasing popularity globally most especially developed counties and developing countries also recently began to pickup.

Scientific research is incomplete without use, adoption, importation or adaption of theories or models. (Adeoye and Olarenwaju, 2019). Therefore the focus of this study is use of Mannes library 2.0 theory to evaluate the library websites of northern private university libraries 
of Nigeria. Mannes (2006) propounded a recent modern library theory coined from web 2.0 known as Library 2.0, which was coined by Michael Casey on his library crunch blog. Mannes (2006) averred that the recent conception describing the web as web 2.0 will have substantial implication for libraries and he recognized that while these implications keep very close to the history and mission of libraries they still necessitate a new paradigm for librarianship. He has given the concept of library 2.0 as "the application of interactive, collaborative, and multi-media web-based technologies to web-based library services and collections," According to him Library 2.0 has four essential theories which are (i) User centered: client are actively in involved in content creation of content and services, in web presence he gave an example of OPAC 2.0 been dynamic where library clients can actively view, edit, and live discussion with librarian.(ii) it provides a multimedia experience: collection and services of Library 2.0 contain video and audio components, which will enhance library user experience i.e. instructional videos on ways to use library links could be available over the web. (iii) It is socially rich: That the library's webpresence includes users' presences. There are both synchronous (e.g. IM) and asynchronous (e.g. wikis) ways for users to communicate with one another and with librarians. (iv). It is communally innovative: This is conceivably the single most important aspect of Library 2.0. It rests on the foundation of libraries as a community service provider, but understands that as communities change, libraries must not only change with them, they must allow community of users to change the library, It seeks to continually change its services, to find new ways to allow communities, not just individuals to seek, find, and utilize information.

Web 2.0 does not replace the existing technology used by libraries but rather adding more value to the services that is provided by the libraries. Private universities in Nigeria and other developing countries are known to be the forerunner of new technology adoption especially the fact that they do not have to rely on government for funds, and has to attract students' patronage that is the reason for picking private universities for this study, since public university library barely have functioning library websites. And lastly also there is dearth or no research conducted to find out the application of web 2.0 to university libraries in Nigeria because of various challenges impeding ICT implementation which necessitate this study. The above context has

raised a research problem stated as follows: To ascertain the application of Web 2.0 in northern private university libraries of Nigeria?

\section{Objectives of the study}

To find out which of the private university libraries websites of northern Nigeria have applied web 2.0

Identify types of web 2.0 technology that are applied to private university libraries of north Nigeria

To identify the purpose of using web2.0 tool on private university libraries websites of north Nigeria. 


\section{Literature review on Application of Web2.0 in libraries websites.}

Mahmood and Richardson (2018) conducted a survey on adoption of web 2.0 in US academic library websites' survey of ARL websites, the websites contents of 100 academic libraries in USA included in the association of research libraries membership list. The analysis shows that many academic libraries provided link to web 2.0 application, RSS feed was found to be the most popular tool followed by instant messaging, the next popular was social networking, with (89) had the presence of Facebook (85) twitter (55) had the presence of social bookmarking or tagging (47) uses Flickr (17) used slide share website for sharing PowerPoint presentation and (10) had the presence of virtual world. Ebrahimzadeh, et.al., (2016). investigates awareness of web 2.0 in Iran academic libraries. Blogs and wikis were the most frequently used for personal purpose such as communication between friends and family, keeping up-to-date and collaboration with colleagues, the librarians believe web 2.0 is most used for sharing resources, and the most inhibiting factor against usage was lack of training, lack of access to high speed internet in same vein Nazim and Hussain (2015) in their study discovered that resource discovery tools, which are used for searching and locating library's local and remote content at single search interface, have not gained impetus in Indian academic libraries and use of blogs, wikis, RSS, feeds social networking in academic libraries in India is uncommon they associated the reason with lack of training in ICT by library Staff. Baro, Ebigbe and Godfrey (2014) did a comparative study of web 2.0 tool usage in South Africa and Nigeria. Questionnaire was sent to top university in South Africa and Nigeria through email.110 questionnaire was returned (67.2\%) from Nigerian and (32.7\%) from South Africa. The result shows that there was significant differences in the use of web2.0 tools among librarians in university libraries in Nigeria and South Africa, librarians in Nigeria use Web 2.0 tools mostly for reference services online, announcing library news/events, training resources and image and video sharing. South Africa utilized more of web 2.0 tools in comparison to Nigeria. Also there are differences in the purpose of use and challenges in the use of web 2.0 tool. The following recommendation were made that university libraries in Nigeria should have an alternative means to provision of stable power supply, library school should be Re-design school curricula to incorporate web2.0, frequent training and workshops should be organized, university management should provide necessary facilities such as computer with internet services, similarly Wood (2009) studied the state of the 23 academic library websites in South Africa. He found some problems with the websites, made recommendation as well as providing some examples of best practices in Tanzania. Han and Liu (2009). analyzed the content of library websites of 38 top universities in China to determine the integration of web2.0 tool and services. Web 2.0 tool include RSS feeds, blogs, wikis, instant messaging, social networking services, web browser tools, tagging cloud, text alerts, podcast, vodcast and lastly OPAC 2.0. The finding shows that web2.0 applications have been applied in two-thirds of the top university 38 libraries surveyed in china with emphasis on OPAC 2.0 and

RSS, while SNS, blog, IM, and wikis are less frequent. Nguyen (2008) conducted a survey on 
application of web2.0 in Australasian university libraries, the author describe web2.0 application in the libraries has an emerging trend. The finding of the study shows that only four types of web2.0 technology were employed in Australasian university libraries, they include RSS, blogs, instant messaging and podcast, however she concluded by saying the general web2.0 application were still low based on benchmarked indexes. Malik and Mahmoud (2014). conducted a study on readiness of university libraries in Punjab to adopt digital reference service. Thirty eight university in total were sampled and response was gotten from mailed questionnaire, the objectives of the study was to explore the readiness level For DRS (Digital Reference service) in Punjab province of Pakistan in terms of organizational awareness, willingness and strength of resources to furnish workable suggestions for developing DRS programs. The findings reveal that only a few libraries were at a level of DRS readiness while others were adopting the system at slow pace.

\section{Scope and limitation of study}

The scope of the present study is limited to private university library websites in north of Nigeria, which include: Baze university, Nile university, African university of science and technology Nigeria, Alhikmah university, Salem university, Veritas university, Alqalam university, American university of Nigeria, Skyline university and Bingham university.

\section{Research Methods}

Online survey method was adopted to select private universities in northern Nigeria, because of the large sample size of universities in Nigeria and because private universities are ICT compliant in comparison to public universities in Nigeria who are impeded, because of several factors and as such are comatose.

\section{Research Sample}

According to National university commission of Nigeria which is a body that regulates universities there are 20 private universities in Nigeria 10 are situated in the northern part of Nigeria. Thus research population is 10 private university library websites. The author decided to collect sample using the following method:

- Create a list of all the 10 private university libraries adapted from national university commission website

- Access of the library websites to identify presence of web 2.0 technologies

- 'Site Search' option of select websites either through the university main website page or library website page were used to find out the application of Web 2.0 by using following keywords such as blog, podcast, vodcast, chat, tagging, RSS, ask librarian, virtual reference, OPAC, Twitter and Face book

- Mark the libraries on the list that used any types of Web 2.0 technologies. 
A website is considered not having any Web 2.0 tools employed when neither library homepage, university homepage nor searching efforts yield any result or website not connecting or unavailable.

\section{Analysis}

Figure 1 indicates only $40 \%(4)$ of the 10 Private university libraries in the north of Nigeria have applied Web2.0 application. This supports studies conducted by Baro et al (2013) that Nigerian academic libraries are sparsely utilizing web2.0 application.

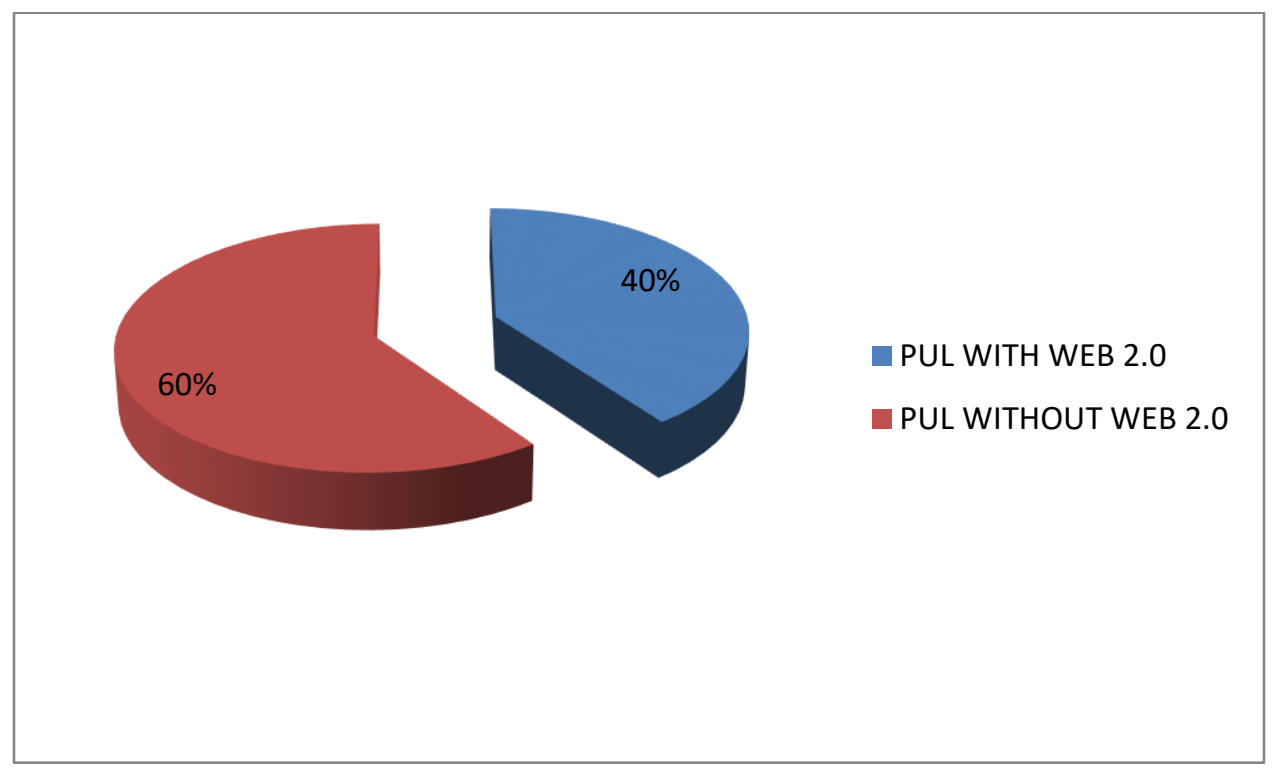

Figure 1:Percentage of private university libraries (PUL) using web 2.0 application

Figure 2 indicates types of web2.0 tool application in library websites of private university in north Nigeria only four select private university libraries in the north have implemented web 2.0 applications they include Nile university, American university of Nigeria, Skyline university, Alhikmah university. the major web 2.0 application in vogue among the northern private university library in Nigeria is WebOPAC only American university of Nigeria have implemented RSS, Veritas, Alhikmah and Nile have implemented SNS. 


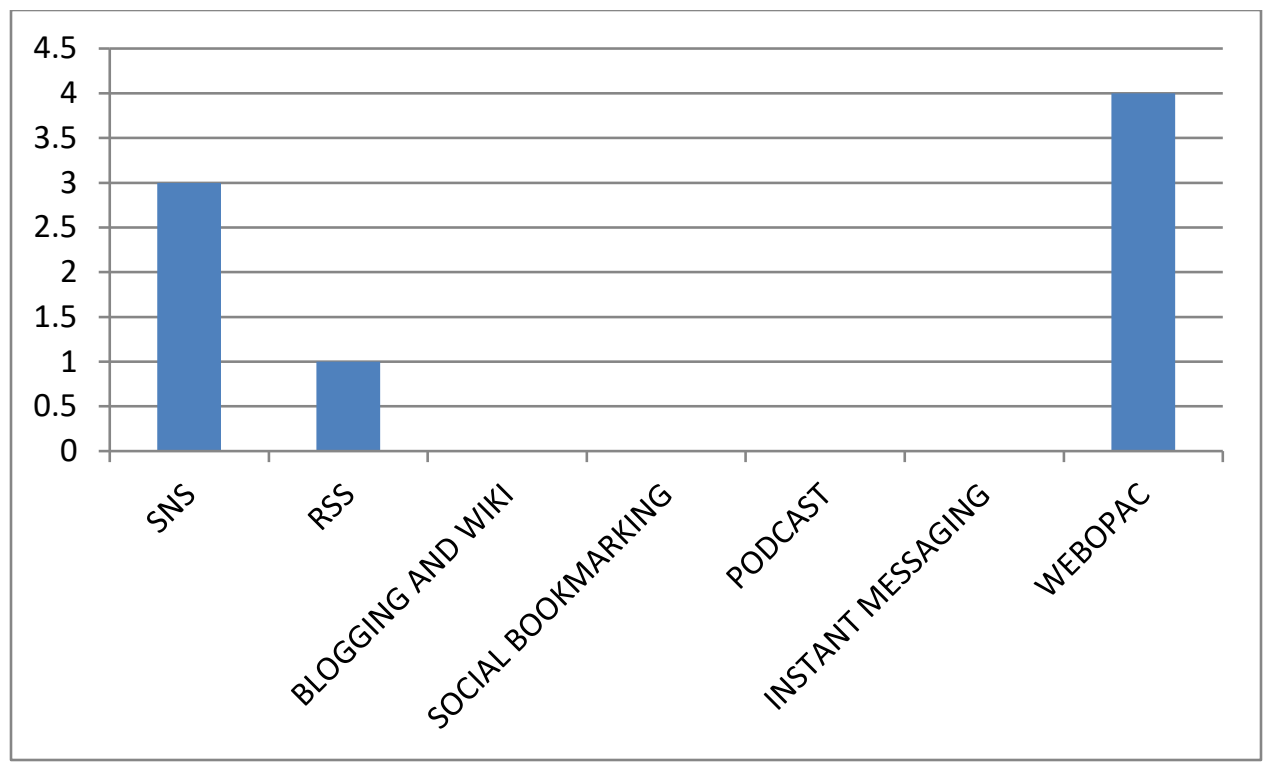

Figure 2: Type of web 2.0 tool

Table 1

\begin{tabular}{|l|l|l|}
\hline S/N & Use of RSS(Number of private university libraries RSS=1) & Frequency \\
\hline 1 & Library news and events & 1 \\
\hline 2 & Providing information about new issue of newsletter & - \\
\hline 3 & Provide information about new acquisition & - \\
\hline 4 & Providing information about addition podcast/vodcast & - \\
\hline 5 & Web aggregator & - \\
\hline 7 & Use as a blog feed & - \\
\hline 8 & Others & - \\
\hline
\end{tabular}

Table 1: indicate that only (1) library of the selected private university library use RSS web 2.0 application on their website and for the purpose of providing library news and events only.RSS stand for Rich Site Summery or Really Simple Syndication or RDF (Resource Description Framework) Site Summery. It is most popular and easy tool among Web 2.0 technologies (Walia and Gupta 2012). It is an extensive Markup language that summarizes websites contents and enables subscribers receive up-to-date contents of other sites without logging in to multiple sites RSS provides benefits of timeliness and convenience. RSS saves time required for logging on to each of these sites and provides current information at convenience of the user this implies that when website is updated the RSS feed also gets updated implying that any registered user will also get updated. (Si et al., 2011 cited in Idiegbeyan, et al., 2019). 
Table 2

\begin{tabular}{|l|l|l|}
\hline S/N & Use of SNS(Social networking sites=3) & Frequency \\
\hline 1 & Photo sharing & - \\
\hline 2 & Video sharing & - \\
\hline 3 & Picture sharing & - \\
\hline 4 & Library news and events & 3 \\
\hline 5 & Sharing links to resources & - \\
\hline 6 & others & - \\
\hline
\end{tabular}

Table 2: Indicates that only 30\% (3) of the selected libraries have applied SNS and the purpose of use is to share library news and events, the most used is Face book among the three private university libraries. Social networking sites such as Face book twitter flicker, Linkedin have been used to foster communication and interaction between librarians and patrons; they are used to enhance visibility of libraries, sharing library newsletters. Social network sites have been used to create awareness of library services (Baro,et al., 2014).

Table 3

\begin{tabular}{|l|l|c|}
\hline S/N & Use of WebOPAC (Number of private university libraries=4) & Frequency \\
\hline 1 & For borrowing & - \\
\hline 2 & For reservation & 1 \\
\hline 3 & Hypertext links to bibliographic records & 3 \\
\hline 4 & Searching all e resources through one interface & - \\
\hline 5 & Others. & \\
\hline
\end{tabular}

Table 3 indicates that the WebOPAC have been applied in 40\%(4) private university libraries in the north of Nigeria, and(3) use it for the purpose of searching E-resources through one interface and (1) private university library website use it for the purpose of provide links to bibliographic records. Web OPAC is an OPAC (open access catalogue which is available on the web: Web OPAC automatically assist user to search the OPAC anywhere, anytime around the world with the use of internet. It eases circulation, allow reservation. (Kumar and Singh,2014).

Some Web 2.0 Tools and Uses in Library and Information centers not applied to any private university library website in north Nigeria.

\section{Instant messaging}


Instant messaging is a synchronous messaging system like what is found on yahoo, AOL, it provides real time communication. Libraries are currently utilizing this tool to provide referencechat services which enables librarians to ask and answer queries from patrons. It provides benefits of instantly resolving patron's challenges. It is currently implemented in library websites which provides interactive features. This service is highly ranked by users as it saves time and proffers instant answers to queries (Mahmood and Richardson,2018).Nigerian academic library websites have not adopted this technology.

\section{Blogs and Wikis}

Blogs are commonly used to generate interest in subject specific topics, as well as to engage users (Chua andGoh, 2010). Blogs are websites entries of user opinions or information appearing in a chronological order. Blogs have been seen to promote interaction among patrons by encouraging user feedback, they also serve as a tool for communicating information, marketing library services, promoting information literacy, providing reference services, dissemination tool for newly acquired items, providing book reviews to patrons, publicizing new books, book discussions, advertising the library.(Idiegbeyan, et al.,2019).while wikis are used by libraries in their websites to cull resources thematically from users, develop subject guides or related contents.

\section{Podcast}

Podcast: is usually in a digital medium that consist of series of audio and video files that can be streamed online or downloaded. In academic libraries its benefits are huge; it has been used to inform patrons on library resources, trainings, research opportunities and events. Podcast have shown great results in the training of patrons on the use of library services ( Tripathi \& Kumar,2010 cited in Idiegbeyan, et al, 2019).

\section{Social bookmarking and Tagging}

Social bookmarking service is an online service which enables users to add, annotate, edit and share bookmarks of web documents. Examples are (http://del.icio.us.com) and Flickr (http://flickr.com), which can be used to add bookmarks and tags to a library websites. (Izuagbe et al., 2014) Social Bookmarking tools are excellent resource discovery tools; in library webpage when searching for a particular subject, users may see that other users tagged a particular web page and other sites under similar tags. This web2.0 application is not utilized in Nigerian academic libraries. 


\section{Discussion and Findings}

The reason for surveying private university libraries websites only in this study is because private university are ICT inclined and equipped to attract student patronage in comparison to other academic libraries in Nigeria who are impoverished by several factors.

The websites of all the private of all the private university libraries in northern Nigeria were working during the survey period. Very few private university library webpage provide links to web 2.0 applications on their page, out 10 surveyed private university library only 4 (40\%) have slightly applied web 2.0 applications. This is in contrast to (Han and Liu,2009),(Mahmood and Richardson,2018) which shows that web 2.0 are adopted and used in developed nations.

WebOPAC is found to be the most popular and the purpose of using the WebOPAC is for user friendliness, searching link to E-resources on one interface and hypertext link to bibliographic records, this is in line with Han and Liu, (2009) which indicate that use of WebOPAC is wide spread and most popular among Chinese universities because catalog presence over the internet has been the focus of Web2.0 in the $21^{\text {st century }}$ library era. The second most popular tool was SNS and the purpose for application on Private university library websites of the north Nigeria was for sharing news and events, the most used was Face book. This is in line with Baro, et al., (2014) that librarians in Africa use Web2.0 application to announce library news and events and Face book was the most used web2.0 application, also in same vein Haryana and Raju, (2010) found that Face book was the most popular web application being used in (3) Indian universities. Only 1 private university apply RSS on their library websites for the purpose of providing Library news and events only this is in contrast with Nguyen,(2008) in his study which observe that RSS was the most widely used web2.0 technology.

The present study reveals that application of web2.0 on websites is low in Nigeria. Several studies have proven that academic libraries in Nigeria are faced with mirage of challenges there by inhibiting appropriate ICT application despite the proven advantages. Baro et al., ( 2014), Nazim and Hussain (2015) mentioned Lack of skills as the main obstacle towards web2.0 application in Africa. Idiegbeyan, et al., (2019). mention, lack of policies to support web2.0,inadequate staff capacity, lack of adequate skill in the use of web2.0,corruption issues, lack of maintenance culture, inadequate ICT infrastructure as the main factors hindering web2.0 tool application in Nigeria.

\section{Conclusion and Recommendation}

In the present scenario with the advancement and application of ICT to library to improve service delivery and changing scenario of librarianship where focus is not about access, but sharing, not about searching, but finding. Web 2.0 application on library websites is considered a good hallmark of a library websites especially with the importance of user participation in 
information community globally. The application of web2.0 have opened new avenue for libraries as they allow them to involve users in their activities and request for feedback to improve their services. From this study it shows that the usage of web2.0 in private university libraries in Nigeria is low or non-existent. To improve the application of Web 2.0 to university libraries websites in Nigeria. The following suggestions were made:

* Nigerian government should formulate policies that will support web2.0 application

* Improve ICT infrastructures for libraries

* Train and retrain library professional to bridge the digital gap

* Restructure library school towards ICT curriculum. This will enable developing countries like Nigeria to take the full benefits of web2.0 in library and information centers.

\section{References}

Adeoye. A.A and Olanrewaju.A.O. (2019) Use of technology acceptance model (TAM) to evaluate library electronic information resources use by undergraduate students of lead city university, Ibadan, Nigeria. Library philosophy and practice (e-journal) .Retrieved June 10th 2019 from https://digitalcommons.unl.edu/libphilprac/

Baro, E. E., Ebiere, J. E., \& Godfrey, V. Z. (2014). Web 2.0 tools usage: A comparative study of librarians in university libraries in Nigeria and South Africa. Library Hi Tech News, 30(5), 10-20.Retrieved June 2019 from :http://dx.doi.org/10.1108/LHTN-04-2013-0021

Chua, A. and Goh, D. (2010). A study of Web 2.0 in library websites. Library and Information Science Research. 32(3), 203-211 Retrieved July 92019 from https://www.researchgate.net/publication/223003900_A_study_of_Web_20_applications in_library_websites

Ebrahimzadeh Pirshahid, S., Naghshineh, N., \& Fahimnia, F. (2016). Knowledge and use of web 2.0 by librarians in university libraries of east Azerbaijan, Iran. The Electronic Library, 34(6), 1013-1030.Retrieved July 1st form doi:http://dx.doi.org/10.1108/EL-10-2014-0192

Han, Z., \& Liu, Y. Q. (2010). Web 2.0 applications in top Chinese university libraries. Library HiTech,28(1),41-62.AcessedJune21st 2019fromhttps://search.proquest.com/docview/742893249? accountid=10461

Harinarayana, N.S. and Raju, N.V. (2010), "Web 2.0 features in university library web sites", The Electronic Library, Vol. 28 No. 1, pp. 69-78. 
Husain.S. Nazim.M, (2015) Use of different information and communication technologies in Indian academic libraries.Library Review, 64 1(2), 135-153. Retrieved April 20th from https://doi.org/10.1108/LR-06-2014-0070

Idiegbeyan.O.J.Okocha.F.Aregbesola.A.Owolabi.S.Eyioilorunsho.T.Yusuf.F.(2019).Application of Web 2.0 Technology in Library and Information Centres in DevelopingCountries: Challenges and Way Forward. Library philosophy and practice (E journal). Retrieved July $10^{\text {th }}$ from https://digitalcommons.unl.edu/libphilprac/2387/

Izuagbe, R., Ifijeh, G., Izuagbe-Roland, E. I., Olawoyin, O. R., \& Ogiamien, L. O. (2019). Determinants of perceived usefulness of social media in university libraries: Subjective norm, image and voluntariness as indicators. The Journal of Academic Librarianship, 45(4), 394-405.

Kumar.R and Singh.J.(2014). A journey of card catalogue to web OPAC. International journal of library and information studies 4(2).Retrieved July 10, 2019 from http://www.ijlis.org/img/2014_Vol_4_Issue_2/38-45.pdf

Mahmood.K. and Richardson.J.V.(2018) Adoption of Web 2.0 in US academic libraries: a survey of ARL library websites.Emerald.45(4).365-375.

Malik,A.M and Mahmoud..K.(2014) Readiness For Digital Reference Service (DRS) in University Libraries: A survey in the Punjab, Pakistan. Information Development 30(2), 181-188

Maness, J. (2006). Library 2.0 Theory: Web 2.0 and Its Implications for Libraries. Webology, 3(2). Retrieved 20th June 2019 from:http://www.webology.org/2006/v3n2/a25.html

Nguyen, L. C. (2008). A survey of the application of web 2.0 in Australasian university libraries. Library Hi Tech, 26(4), 630-653. Retrieved June22nd 2019 from https://search.proquest.com/docview/57705301?accountid=1046

Walia.P.K.andGupta.M.(2012).Application of Web2.0 by national libraries. $\begin{array}{llll}\text { Webology,9(2).Retrieved } & \text { July } & 10^{\text {th }}\end{array}$ fromhttp://www.webology.org/2012/v9n2/a99.html

Wood .M. (2009).Academic library websites in South Africa, Innovation, 39 (1),43-57 